\title{
A Review on Noma: A Recent Update
}

\author{
Nipun Ashok ${ }^{1}$, Bassel Tarakji ${ }^{1}$, Shorouk Darwish ${ }^{1}$, Jean C. Rodrigues ${ }^{2} \&$ Mohammad A. Altamimi $^{2}$ \\ ${ }^{1}$ Department of Oral and maxillofacial sciences, Alfarabi College of dentistry and nursing, Riyadh, Saudi Arabia \\ ${ }^{2}$ Department of Restorative dentistry, Alfarabi College of dentistry and nursing, Riyadh, Saudi Arabia \\ Correspondence: Bassel Tarakji, Department of Oral and maxillofacial sciences, Alfarabi College of dentistry \\ and nursing, Riyadh, Saudi Arabia. Tel: 966-504-623-330. E-mail: denpol@yahoo.co.uk
}

Received: May 4, 2015 Accepted: June 10, 2015 Online Published: July 30, 2015

doi:10.5539/gjhs.v8n4p53 URL: http://dx.doi.org/10.5539/gjhs.v8n4p53

\begin{abstract}
Noma is a gangrenous infection primarily affecting under developed countries. The aim of this paper was to review all recent articles on noma from January 2003 to August 2014 and briefly update the latest information related to the topic. A literature search was done on PUBMED using the keywords "noma / cancrum oris". Noma is commonly seen in malnourished children. There has been an increased incidence of noma in HIV patients. Apart from these, noma has also been reported in association with cyclic neutropenia, herpetic stomatitis, leukemia, Down's syndrome and Burkett's disease. Treatment of acute noma includes transfusion of blood and intravenous fluids, administration of antibiotics, putting the patient on a high protein diet and debridement of necrotic areas. Surgical phase is usually initiated 6 to 18 months after a period of quiescence. Although, the mortality rate associated with noma has reduced significantly with the advent of modern generation antibiotics, the functional, cosmetic and psychological challenges associated with the destruction of soft or hard tissues still remains a huge challenge. Adequate steps must be implemented by the government or medical professionals to prevent the disease and provide an early intervention.
\end{abstract}

Keywords: cancrum oris, gangrene, noma, pathogenesis

\section{Introduction}

Noma is a "gangrenous affection of the mouth, especially attacking children in whom the constitution is altered by bad hygiene and serious illness especially from eruptive fevers, beginning as an ulcer of the mucous membrane with edema of the face extending from within out, rapidly destroying the soft tissues and the bone and almost always quickly fatal". The term noma originates from the greek word "nomein" which means to devour or to graze (Auluck \& Pai, 2005).

\section{Methods}

Although the incidence of noma is very high in undeveloped countries and the consequence very severe, it has not received much attention. The aim of this paper was to review the recent articles on noma and update the latest information regarding noma. A literature search was done for articles on PUBMED using the keywords noma, cancrum oris from January 2003 till August 2014. A total of 44 articles were included in the review, which gave an insight to the history, epidemiology, risk factors, pathogenesis, microbiology, complications and management of noma.

\section{History}

Noma was described in ancient Greek and roman medical texts and was found to be common by medieval and renaissance European writers (Vinetz, 2008). Noma was first reported by Hippocrates in $5^{\text {th }}$ century B.C (Baratti-Mayer et al., 2003). In the $19^{\text {th }}$ century, A.L Richter reported the presence of noma throughout Europe and he associated this disease with malnutrition and childhood infection such as measles. Noma had almost disappeared from Europe and North America by the end of the $19^{\text {th }}$ century, except for the cases seen in concentration camps during the Second World War, but there has been an increasing incidence of this disease in underdeveloped countries. In 1994, the World Health Organization (WHO) described noma as a health priority and an action program was initiated involving the WHO, the United States National institute of health and the University of Maryland, Baltimore (K. Ogbureke \& E. Ogbureke, 2010). 


\section{Epidemiology and Risk Factors}

The annual incidence and prevalence of noma was reported to be $1,40,000$ and 7,70,000 cases respectively (Enwonwu, 2006; Tonna, Lewin, \& Mensh, 2010). Finding the exact incidence and prevalence of noma was difficult because of the high mortality rate, incidence in underdeveloped countries, difficulty in registering, controlling and following up because of the affected people being nomadic and the isolation of patients because of the social stigma associated with noma (Baratti-Mayer et al., 2003).

Most cases of noma are reported from the so-called noma belt, which is located south of the Sahara and runs across Africa from Senegal to Ethiopia (Marck, 2013). Recently, isolated cases of noma have been reported from developed countries (Chiandussi, Luzzati, Tirelli, Di Lenarda, \& Biasotto, 2009). Noma is commonly seen in a population with extreme poverty, severe malnutrition, unsafe drinking water, poor sanitation, poor oral health practices, high infant mortality, limited access to high quality health care and intrauterine growth retardation (Tonna et al., 2010). Recently, an increased incidence of noma has been reported in patients with Human Immune deficiency Virus (HIV) infection (Baratti-Mayer et al., 2003; Marck, 2013). Cases of noma reported in HIV patients are shown in Table 1. Noma was also reported in patients with cyclic neutropenia (Erbagci, 2003), leukemia (Santos, Neri, \& Chiattone, 2011), Down's syndrome (Lembo, De Leonibus, Francia, Lembo, \& Ayala, 2011), Burkett's disease (Millogo, Konsem, Ouedraogo, Ouoba, \& Zwetyenga, 2012) and herpetic stomatitis (Fasola, Obiechina, \& Arotiba, 2003).

Table 1. Noma cases reported in HIV patients

\begin{tabular}{ll}
\hline Authors (year) & Number of cases \\
\hline Faye et al. (2003) & 2 \\
Ondzotto, Ibara, Mowondabeka, \& Galiba (2004) & 4 \\
Naidoo \& Chikte (2004) & 1 \\
Chidzonga \& Mahomva (2008) & 48 \\
Chidzonga \& Mahomva (2008) & 1 \\
Diallo, Camara, Bah, Barry, \& Cisse (2009) & 5 \\
Pacheco-Tenza, Hernandez-Ros, Gregori-Colome, \& Navarro-Lopez V (2010) & 1 \\
Koech KJ (2010) & 1 \\
Millogo, Konsem, Ouedraogo, Ouoba, \& Zwetyenga (2012) & 14 \\
Lubala, Mutombo, Mukuku, Ilunga, \& Shongoya (2012) & 1 \\
Masipa et al. (2013) & 2 \\
Van niekerk, Khammissa, Altini, Lemmer, \& Feller (2014) & 1 \\
\hline
\end{tabular}

Malnutrition is considered to be an important risk factor for noma (Baratti-Mayer et al., 2003). In Africa, most of the cases were reported during the dry season when food is scarce and when incidence of measles is highest (Enwonwu, Falkler, \& Philips, 2006). Debilitating diseases like malaria and measles were considered to be a significant risk factors or precursors to noma. Measles could be an important risk factor because of the associated immunosuppression (Baratti-Mayer et al., 2003).

A recently conducted prospective study by Baratti-Mayer et al. (2013) concluded the predictors of noma to be severe malnutrition, recent respiratory or diarrhoeal syndrome, the number of previous pregnancies in the mother, an altered oral microbiota when compared with controls and the absence of chickens at home. According to Adeola and Obiadazie (2009), some cases in northern Nigeria resulted due to the lack of maternal care, where mothers leave their babies in the care of their grandmother as soon as they are delivered, as they have to compete with their mates for the husband. Grandmothers are less educated regarding a balanced diet leading to malnourishment in babies and resulting in noma.

\section{Pathogenesis}

The exact etiology of noma is not known but it is believed to be multifactorial in nature. Researchers initially believed that bone exposure caused by acute necrotizing ulcerative gingivitis (ANUG) could act as a passage point for noma. But the present consensus is that ANUG is a precursor for noma (Baratti-Mayer et al., 2003). 
It is suggested that factors such as malnutrition, weakened immune functions and prior viral infection, all worsened by poor oral hygiene could lead to reduction in host resistance and favor the development of oral ulcers. These lesions can serve as entry sites for microorganisms responsible for the disease process (Huyghe et al., 2013). When poverty prevails, there appears to be a synergistic relation between malnutrition, weakened immune functions and increased susceptibility to infections. In malnourished subjects, IgA, an important component of the mucosal immune system, is significantly reduced whereas plasma concentration of pro-inflammatory cytokines and C-reactive protein is increased when compared to healthy counterparts. Infections such as AIDS, measles and malaria could also lead to a shift from pro-inflammatory cytokines to anti-inflammatory cytokines (Enwonwu et al., 2006).

Rapid destruction of hard and soft tissues seen in noma could be attributed to immunopathological response to microbial factors rather than microbiological factors alone. Enwonwu, Phillips and Savage (2005) found higher plasma levels of anti-inflammatory and pro-inflammatory cytokines in children with necrotizing ulcerative gingivitis when compared to controls. Research has shown that oral epithelial cells and other resident cells secrete several pro-inflammatory cytokines and chemokines in response to bacterial products which in turn can stimulate the expression of matrix metalloproteinase. This matrix metalloproteinase can cause destruction of both hard and soft tissues (Enwonwu et al., 2006).

\section{Microbiology}

Noma being an opportunistic infection, the role of specific microorganisms in the pathogenesis has not been explained. This is because of a large range of uncultivable microorganisms, the disease usually develops rapidly in remote geographic areas making it difficult for early microbiological analysis and its prevalence in populations whose normal oral flora is poorly investigated (Huyghe et al., 2013). Recent advancements in microbial techniques have helped in better identification and characterization of microorganisms seen in noma.

A number of potential pathogens were found in abundance in the sites of noma which include Prevotella melaninogenica, Corynebacterium pyogenes, Fusobacterium nucleatum, Bacteroides fragilis, Bacillus cereus, Prevotella intermedia and Fusobacterium necrophorum (Baratti-Mayer et al., 2003). Microbial analysis in the early $20^{\text {th }}$ century revealed the presence of spirilliform and fusiform microorganisms in biopsy samples taken from the transitional zone between gangrenous and healthy tissues (Marck, 2013). Later studies reported that Fusobacterium necrophorum, a predominant animal pathogen to be the most common microorganism isolated from the disease sites in Nigerian children. It was suggested that Fusobacterium necrophorum could be a trigger organism for noma. This microorganism produces various toxins and has been associated with necrotizing infections in animals and it may contaminate livestock and potentially infect children (Enwonwu et al., 2006; Baratti-Mayer et al., 2013).

A recent study conducted by Hughye et al. (2013) contradicted the involvement of Fusobacterium necrophorum as an etiologic agent. Known periodontal pathogens like aggregatibacter actinomycetemcomitans, capnocytophaga, porphyromonia and fusobacteria were more prevalent in healthy samples compared to those with noma. Studies by Hughye et al. (2013) and Bolivar et al. (2012) identified prevotella intermedia and peptostreptococus to be more clearly associated with noma.

\section{Clinical Features}

Systemic manifestations of noma include fever, tachycardia, lymphadenopathy, high respiratory rate, anorexia, general edema and ascites. Medical history reveals a parasitic or viral infection (measles, malaria) in the recent past, recurrent fever and diarrhea. Blood examination reveal a low hemoglobin concentration and white blood cell count, elevated erythrocyte sedimentation rate and hypoalbuminaemia (Auluck \& Pai, 2005; Enwonwu et al., 2006; Baratti-Mayer et al., 2013). Fresh cases of noma are seen primarily in the 1 to 4 age group. Children with acute noma suffer from linear growth retardation and are severely affected (Enwonwu, Philips, \& Ferrell, 2005; De Onis \& Blosner, 2003). The course of noma is very rapid and death can occur in some days. HIV patients reported with noma may have a very low CD4 count (Masipa et al., 2013).

It is believed that noma is an extension of necrotizing ulcerative gingivitis (NUG) which is characterized by gingival edema, necrosis, bleeding and pain (Enwonwu et al., 2006). NUG may progress to necrotizing periodontitis (NP) and later to necrotizing stomatitis. In necrotizing stomatitis, NUG or NP spread beyond the mucogingival junction to affect the alveolar, buccal, lingual or palatal mucosa. Untreated necrotizing stomatitis may progress to noma, but some cases of noma are reported without a previous history of necrotizing stomatitits (Masipa et al., 2013).

The first recognized sign of noma is edema of cheek, or gingiva or both. A greyish black area appears on the 
external surface of the cheek opposite to the intraoral lesion within the next few days, which later on becomes a well-defined black necrotic zone. This necrotic zone acquires a cone shape and rapidly sloughs away (Enwonwu et al., 2006). Intra-oral manifestations include sequestration of the exposed bone and teeth, halitosis, pseudomembranes, excessive salivation, spontaneous gingival bleeding and loss of tips of interdental gingival papilla. Sometimes the necrosis is very severe that both maxilla and mandible are completely destroyed extending up till the nose, upper lip, pre-maxilla and the infraorbital margin (Baratti-Mayer et al., 2003; Enwonwu et al., 2006; Tonna et al., 2010; Baratti-Mayer et al., 2013).

\section{Differential Diagnosis}

Differential diagnosis for noma includes leprosy, leishmaniasis, post kala-azar dermal leishmaniasis, oral cancer, clostridial or streptococcal gangrene and Stewart's granuloma (Tonna et al., 2010). Neonatal noma is a rare clinical syndrome with gangrene of orofacial tissues involving both term and preterm infants in the first week of life and resembles noma in older children (Auluck \& Pai, 2005). The predisposing factors for noma neonatorum are considered to be preterm birth weight and severe intrauterine growth retardation (Enwonwu, 2006). Some authors believe that neonatal noma is a distinct identity, where neonates are affected with pseudomonas sepsis (Baratti-Mayer et al., 2003; Vaidyanathan, Tullu, Lahiri, \& Deshmukh, 2005).

\section{Complications}

Mortality used to be a common complication of noma. With the use of modern antibiotics and better nutrition, mortality rate has reduced from $90 \%$ to $8-10 \%$ (Auluck \& Pai, 2005; Marck, 2003). Noma can result in trismus, sequestration of jaws, fibrous ankylosis of temporomandibular joint, oro-nasal fistula, damage to permanent tooth bud, early loss of decidious teeth and hypoplasia of maxilla or mandible. Most of the noma patients have difficulty in mastication because of loss of soft and hard tissue. Severe cosmetic disfigurement can also take place from the resulting scarring and loss of tissue (Holle, 2009; Jayasankar, Chavda, \& Shah, 2004; Woon, Sng, Tan, \& Lee, 2010). According to Yunusa and Obembe (2012), patients reported of a high psychiatric morbidity after noma.

\section{Management and Prevention}

Acute noma is managed by blood transfusion, transfusion with intravenous fluid for correction of dehydration and electrolyte imbalances, treatment of associated diseases like malaria and measles, the administration of antibiotics and putting the patient on a high protein diet (Auluck \& Pai, 2005; Enwonwu, 2006). The affected area has to be debrided with dilute hydrogen peroxide or Edinburgh university solution of lime (EUSOL) or saline and any remaining tissue slough and sequestrate has to be removed. A course of antibiotics (ampicillin-cloxacillin and metronidazole), multivitamin preparation and antiseptic therapy has to be administered for a week. Patients are advised to rinse their mouth with chlorhexidine gluconate $(0.12-0.2 \%)$ daily. The patient has to be screened for HIV infection and referred appropriately (Baratti-Mayer et al., 2003; Enwonwu et al., 2006; Baratti-Mayer et al., 2013).

Surgical correction is initiated after a period of disease quiescence of at least 6 to 18 months. The aim of the surgical procedure is to restore oral speech, oral competence and acceptable aesthetics. Reconstructive surgery in children is delayed till the patient matures because it allows the defect to contract and reduce in size, allows sufficient cooperation postoperatively and ensures adequate tissue for reconstruction. Trismus which most often results from extra-articular ankyloses (fibrosis) is corrected by complete excision of fibrosis followed by physiotherapy (Woon et al., 2010; Baratti-Mayer et al., 2013). Closure of tissue defects is usually done by local, pedicled or free flaps. Various techniques employed include prefabricated scapular flaps, free radial forearm flap, anterolateral thigh flap, pedicled supraclavicular flap, waltzing flap and Gillies fan flap (Woon et al., 2010; Hartman, Van Damme, Sauter, \& Suominen, 2006; Giessler et al., 2007; Vinzenz, Holle, \& Wuringer, 2008; Hartman, Van Damme, Rayatt, \& Kuokkanen, 2010; Bello, 2012). An analysis by Bouman et al. (2010), found early success rate of $59 \%$ after surgical treatment of noma, but the success rate was significantly reduced after complex surgical procedures.

Measures needed to prevent noma include administration of nutritious food, exclusive breast feeding during the first three to six months of life, inculcation of proper oral hygiene practices, immunization against endemic diseases like measles, segregation of animals from human living areas and creating a proper awareness about noma (Enwonwu, 2006).

\section{Conclusion}

Noma is a debilitating disease primarily affecting the poor and has been called the "face of poverty". It occurs among the underprivileged society where patients do not have access to good medical care. Noma can be 
prevented to a large extent by providing good nutrition and water facilities, vaccinations and by maintaining good hygiene. The government and health organizations need to take adequate steps to improve the social living conditions of individuals living in noma susceptible areas. Efforts should be made by medical professionals to provide early intervention and medical care to the patients so that mortality can be reduced and tissue destruction can be minimized.

\section{Conflict of Interest}

Authors declare there is no conflict of interest in this manuscript. This study was self-funded by the authors.

\section{References}

Adeola, D. S., \& Obiadazie, A. C. (2009). Protocol for managing acute cancrum oris in children. An experience in five cases. Afr J Pediatr Surg, 6(2), 77-81. http://dx.doi.org/10.4103/0189-6725.54767

Auluck, A., \& Pai, K. M. (2005). Noma: Life Cycle of a Devastating Sore- Case Report and Literature Review. $J$ Can Dent Assoc, 71(10), 757.

Baratti-Mayer, D., Pitte, B., Montandon, D., Bolivar, I., Bornand, J., Hugonnet, S. ... Pittet, D. (2003). Noma: an infectious disease of an unknown etiology. Lancet Infect Dis, 3, 419-31. http://dx.doi.org/10.1016/S1473-3099(03)00670-4

Baratti Mayer, D., Gayet- Ageron, A., Huggonet, S., Francois, P., Pittet- Cuenod, B., Huyghe, A. ... Pittet, D. (2013). Risk factors for noma disease: a 6 year prospective matched case control study in Niger. Lancet Glob Health, 1, e87-96. http://dx.doi.org/10.1016/S2214-109X(13)70015-9

Bello, S. A. (2012). Gillies fan flap for reconstruction of upper lip defect caused by noma: Case presentation. Clin Cosmet Investig Dent, 4, 17-20. http://dx.doi.org/10.2147/CCIDEN.S31190

Bolivar, I., Whiteson, K., Stadelmann, B., Baratti-Mayer, D., Gizard, Y., ... Pittet, D. (2012). Bacterial diversity in oral samples of children in niger with acute noma, acute necrotizing gingivitis, and healthy controls. PLoS Negl Trop Dis, 6, e1556. http://dx.doi.org/10.1371/journal.pntd.0001556

Bouman, M. A., Marck, K. W., Griep, J. E., Marck, R. E., Huijing, M. A., \& Werker, P. M. (2010). Early outcome of noma surgery. $J$ Plast Reconstr Aesthet Surg, 63(12), 2052-6. http://dx.doi.org/10.1016/j.bjps.2010.02.012

Chiandussi, S., Luzzati, R., Tirelli, G., Di Lenarda, R., \& Biasotto, M. (2009). Cancrum oris in developed countries. Aging Clin Exp Res, 21(6), 475-7. http://dx.doi.org/10.1007/BF03327447

Chidzonga, M. M., \& Mahomva, L. (2008). Recurrent noma (cancrum oris) in human immunodeficiency virus infection and acquired immunodeficiency syndrome (HIV and AIDS): Report of a case. J Oral Maxillofac Surg, 66(8), 1726-30. http://dx.doi.org/10.1016/j.joms.2007.08.012

Chidzonga, M. M., \& Mahomva, L. (2008). Noma (cancrum oris) in human immunodeficiency virus infection and acquired immunodeficiency syndrome (HIV and AIDS): clinical experience in Zimbabwe. J Oral Maxillofac Surg, 66(3), 475-85. http://dx.doi.org/10.1016/j.joms.2007.09.024

De Onis, M., \& Blosner, M. (2003). The world health organization global database on child growth and malnutrition: methodology and applications. Int $J$ Epidemol, 32, 518-26. http://dx.doi.org/10.1093/ije/dyg099

Diallo, O. R., Camara, S. A., Bah, A. T., Barry, M., \& Cisse, A. (2009). Cancrum oris in children infected by HIV in the Conakry Teaching Hospital: 5 cases. Mali Med, 24(3), 71-4.

Enwonwu, C. O., Phillips, R. S., \& Savage, K. O. (2005). Inflammatory cytokine profile and circulating cortisol levels in malnourished children with necrotizing ulcerative gingivitis. Eur Cytokine Netw, 16, 240-48.

Enwonwu, C. O., Philips, R. S., \& Ferrell, C. D. (2015). Temporal relation between the occurrence of fresh noma and the timing of linear growth retardation in Nigerian children. Trop Med Int Health, 10(1), 65-73. http://dx.doi.org/10.1111/j.1365-3156.2004.01351.x

Enwonwu, C. O. (354). Noma- The ulcer of extreme poverty. $N$ Eng $J$ Med, 354(3), 221-4. http://dx.doi.org/10.1056/NEJMp058193

Enwonwu, C. O., Falkler, W. A., \& Philips, R. S. Noma (Cancrum Oris). (2006). Lancet, 368, 147-56. http://dx.doi.org/10.1016/S0140-6736(06)69004-1

Erbagci, Z. (2003). Noma-like gangrenous cheilitis in a child with cyclic neutropenia associated with $\begin{array}{llll}\text { myeloperoxidase } \quad \text { deficiency. } & \text { Pediatr }\end{array}$ 
http://dx.doi.org/10.1111/j.1525-1470.2003.20614.x

Fasola, A. O., Obiechina, A. E., \& Arotiba, J. T. (2003). Unusual presentation of NOMA: A case report. Afr J Med Med Sci., 32(4), 417-8.

Faye, O., Keita, M., N'diaye, H. T., Konare, H. D., Darie, H., Keita, S., \& Mahe, A. (2003). Noma in HIV-infected adults. Ann Dermatol Venereol, 130(2 Pt 1), 199-201. [In French]

Giessler, G. A., Cornelius, C. P., Suominen, S., Borsche, A., Fieger, A. J., Schmidt, A. B., \& Fischer, H. (120). Primary and secondary procedures in functional and aesthetic reconstruction of noma-associated complex $\begin{array}{lllll}\text { central facial defects. Plast Reconstr Surg, } & \text { 120(1), }\end{array}$ http://dx.doi.org/10.1097/01.prs.0000263657.49956.8d

Hartman, E. H., Van Damme, P. A., Sauter, H., \& Suominen, S. H. (2006). The use of the pedicled supraclavicular flap in noma reconstructive surgery. J Plast Reconstr Aesthet Surg, 59(4), 337-42. http://dx.doi.org/10.1016/j.bjps.2005.10.005

Hartman, E. H., Van Damme, P. A., Rayatt, S., \& Kuokkanen, H. O. (2010). Return of the waltzing flap in noma reconstructive surgery: revisiting the past in difficult circumstances. J Plast Reconstr Aesthet Surg, 63(1), e80-1. http://dx.doi.org/10.1016/j.bjps.2009.01.011

Holle, J. (2009). Lockjaw treatment after noma in the third world. J Craniofac Surg., 20(Suppl 2), 1910-2. http://dx.doi.org/10.1097/SCS.0b013e3181b6c6e2

Huyghe, A., Francois, P., Mombelli, A., Tangomo, M., Girard, M., Baratti-Mayer, D. et al. (2013). Microarray analysis of microbiota of gingival lesions in noma patients. PLoS Negl Trop Dis, 7(9), e2453. http://dx.doi.org/10.1371/journal.pntd.0002453

Jayasankar, P. P., Chavda, J., \& Shah, R. M. (2004). Oro-nasal fistula of infective origin and alveolar necrosis in a 13 year old boy. Indian J Dent Res, 15(3), 107-9.

Koech, K. J. (2010). Cancrum oris in an adult with human immunodeficiency virus infection: case report. East Afr Med J, 87(1), 38-40. http://dx.doi.org/10.4314/eamj.v87i1.59953

Lembo, S., De Leonibus, C., Francia, M. G., Lembo, C., Ayala, F. (2011). Cancrum oris in a boy with Down syndrome. J Am Acad Dermatol, 64(6), 1200-2. http://dx.doi.org/10.1016/j.jaad.2009.08.048

Lubala, T. K., Mutombo, A. M., Mukuku, K. O., Ilunga, M. P., \& Shongoya, M. P. (2012). Association acute noma - HIV - severe malnutrition in children. Pan Afr Med J., 13, 1. [ in French]

Marck, K. W. (2003). A history of noma, the "Face of Poverty". Plast Reconstr Surg, 111(5), 1702-1707. http://dx.doi.org/10.1097/01.PRS.0000055445.84307.3C

Marck, K. W. (2013). Noma: a neglected enigma. Lancet Glob Health, 1(2), e58-59. http://dx.doi.org/10.1016/S2214-109X(13)70035-4

Masipa, J. N., Baloyi, A. M., Khammissa, R. A., Altini, M., Lemmer, J., \& Feller, L. (2013). Noma (cancrum oris): A report of a case in a young AIDS patient with a review of the pathogenesis. Head Neck Pathol, 7(2), 188-92. http://dx.doi.org/10.1007/s12105-012-0393-0

Millogo, M., Konsem, T., Ouedraogo, D., Ouoba, K., \& Zwetyenga, N. (2012). HIV and noma in 3Burkina Faso. Rev Stomatol Chir Maxillofac, 113(6), 433-6. [in French] http://dx.doi.org/10.1016/j.stomax.2012.07.004

Naidoo, S., \& Chikte, U. (2004). Oro-facial manifestations in paediatric HIV: A comparative study of institutionalized and hospital outpatients. Oral Dis, $10(1), \quad 13-8$. http://dx.doi.org/10.1046/j.1354-523X.2003.00973.x

Ogbureke, K. U., \& Ogbureke, E. I. (2010). Noma: a preventable scourge of African children. Open Dent J, 4, 201-206. http://dx.doi.org/10.2174/1874210601004010201

Ondzotto, G., Ibara, J. R., Mowondabeka, P., \& Galiba, J. (2004). Cervico-facial and ENT symptoms due to HIV infection in tropical area. About 253 Congolese cases. Bull Soc Pathol Exot, 97(1), 59-63. [In French]

Pacheco-Tenza, M. I., Hernandez-Ros, R., Gregori-Colome, J., \& Navarro-Lopez, V. (2010). A 50-year-old HIV-infected woman with a cheek perforation. Enferm Infecc Microbiol Clin, 28(4), 254-5. [In Spanish] http://dx.doi.org/10.1016/j.eimc.2009.05.011

Santos, P. S., Neri, N. B., \& Chiattone, C. S. (2011). Noma-like lesion in a patient with acute promyelocytic leukemia. Rev Bras Hematol Hemoter, 33(4), 321-2. http://dx.doi.org/10.5581/1516-8484.20110087 
Tonna, J. E., Lewin, M. R., Mensh, B. R. A case and review of noma. PLoS Negl Trop Dis, 4(12), e869. http://dx.doi.org/10.1371/journal.pntd.0000869

Vaidyanathan, S., Tullu, M. S., Lahiri, K. R., \& Deshmukh, C. T. (2005). Pseudomonas sepsis with noma: An association? Indian J Med Sci, 59(8), 357-360. http://dx.doi.org/10.4103/0019-5359.16653

Van Niekerk, C., Khammissa, R. A., Altini, M., Lemmer, J., \& Feller, L. (2014). Noma and cervicofacial necrotizing fasciitis: Clinicopathological differentiation and an illustrative case report of noma. AIDS Res Hum Retroviruses, 30(3), 213-6. http://dx.doi.org/10.1089/aid.2013.0259

Vinetz, J. M. (2008). Missing the forest for trees in biomedical research: The example of noma. Am. J. Trop. Med. $78(4), 535$.

Vinzenz, K., Holle, J., \& Wuringer, E. (2008). Reconstruction of the maxilla with prefabricated scapular flaps in noma patients. Plast Reconstr Surg, 121(6), 1964-73. http://dx.doi.org/10.1097/PRS.0b013e3181706dd6

Woon, C. Y., Sng, K. W., Tan, B. K., \& Lee, S. T. (2010). Case report Journey of noma face. Eplasty, 30(10), e49.

Yunusa, M., \& Obembe, A. (2012). Prevalence of psychiatric morbidity and its associated factors among patients facially disfigured by cancrum oris in Nigeria a controlled study. Niger J Med, 21(3), 277-81.

\section{Copyrights}

Copyright for this article is retained by the author(s), with first publication rights granted to the journal.

This is an open-access article distributed under the terms and conditions of the Creative Commons Attribution license (http://creativecommons.org/licenses/by/3.0/). 